\title{
Demand pattern and willingness to pay for high value fishes in India
}

\author{
Shyam S. Salim \\ Central Marine Fisheries Research Institute, PB.No.1603, Ernakulam North P.0. Kochi- 682018, Kerala, India. \\ *Correspondence e-mail: shyam.icar@gmail.com
}

Received: 12 June 2013, Accepted: 25 Nov 2013, Published: 15 Jan 2014

Original Article

\begin{abstract}
The fish consumption pattern across 540 urban middle income consumers was studied in metropolitan cities of Chennai, Mumbai and Cochin in India. The study focused on income and expenditure pattern, buying behaviour, constraints in fish consumption and willingness to pay (WTP) for high value fishes among the consumers. WTP was determined using logit model. Domestic prices were 20-25 percent more than export price nevertheless a sizeable demand exists with high consumer surplus. The constraint analysis indicated reduced availability, seasonal consumption and exorbitant price of fish in the domestic market. Most domestic consumers were unaware about the low export price and around 50 percent indicated then WTP for if available. The study exposed significant deleterious effect of fish demand - supply mismatch in domestic market. The study advocates governmental interventions in regulating fish exports to ensure domestic fish food security and substituting exports with domestic marketing considering the sizeable WTP.
\end{abstract}

Keywords: Consumption pattern, high and low value fishes, Constraint analysis, Garrett ranking, Logit model.

\section{Introduction}

The domestic market for fish in India is governed not only by the purchasing power of the consumers but also by their tastes and preferences (Sathiadas, 1998). About 30-35 percent of the population in India is vegetarian. Indian domestic market for fish is inelastic both in terms of income and price. The cross price elasticity of fish in India is also inelastic on account of the large size of the country and its population, fish commands practically a niche market in India (Krishnan, 1997). According to ESN Nutrition country profile for India, FAO has reported that fish and seafood provide 2 percent of the dietary energy supply while cereals supply 62 percent $(\mathrm{FAO}, 2005)$. The per capita annual consumption of fish is estimated to be $5 \mathrm{~kg} / \mathrm{yr}$ for the whole population and it is $8 \mathrm{~kg}$ for the non-vegetarian population of the country as against the world average of $16 \mathrm{~kg}$. It may be noted that the cited study puts the rate of growth of fish consumption in India and the South East Asia as having doubled over a period of 1973-1997(Delgado, 2003)

The regional tastes and preferences of fish eating population of the country and the frequency of fish consumption also exert substantial influence on the market (Shyam, 2012). The exportability of a fish and the quantity landed bear a direct relationship to its price in the local market (Krishnan, 1997, 2002). Consumption of fish in India is increasing significantly due to lifestyle changes and higher cost of meat. In addition, the perception of fish as a healthy food with high levels of

J. Mar. Biol. Ass. India, 55 (2), 48-54, July-December 2013 
digestible protein, PUFA and cholesterol- lowering capability is also a major factor for its increased consumption. Sutanuka (2011) stated that this phenomenon is gradually spreading beyond hypermarkets and supermarkets.

The price comparison of the high value species like shrimps, cephalopods, pomfrets and seer fish indicated that the domestic prices were on an average 20-25 percent more than the export prices (Shyam et al., 2010), (Sandu and Shyam, 2012). The exporter's in order to reap in the export economies of scale tend to export more quantity at a lower price margin. The revenue gains are contributed mostly by quantity effect rather than the price effect. The paradox of selling more quantity at a lower export price coupled with alerts and rejections necessitates the need for harnessing the domestic markets so that the fish food available across the Indian masses (Shyam and Geetha, 2011). While the exports earn us valuable foreign exchange, the diversion of fish and fishery products from local communities may lead to food insecurity. Thus, there exists a question of availability and affordability of high value fishes in domestic market (Shyam, 2012). The major objective of the present study was to ascertain the status of fish consumption in selected locations of the country and to determine the factors contributing to the consumption. The specific objectives were to analyse the expenditure and consumption patterns of fishes, assess the demand pattern and awareness for high value and low value fishes, estimate the WTP for selected high value fishes and to analyze the different constraints in the consumption of high value fishes.

\section{Material and methods}

The marine fish landings and consumption varies across coastal states in India. However states like Tamil Nadu, Maharashtra and Kerala has sizeable marine production and consumption and inhabits significant population with high income groups. It is assumed that high value of fish consumption tends to positively associate with fish availability and affordability. The present study analysed the fish consumption pattern across urban consumers in Cochin, Chennai and Mumbai. Cochin, Chennai, Mumbai are metropolitan cities in India inhabiting significant middle and high income population whose purchasing power is considerably higher in comparison with other cities. The primary data was collected from 540 consumer households from Chennai, Mumbai and Cochin. The details on the general particulars like age, education, income, pattern or expenditure, fish consumption, buying behaviour, constraints in high value fish consumption and WTP for high value fishes were collected. The data was collected during January - December 2012.

The primary data on the pattern of expenditure, fish consumption, buying behavior, constraints in high value fish consumption, WTP for high value fishes etc. were collected from 540 consumer households during Jan-Dec 2012. Willingness to pay (WTP) is the price that someone is willing to give up or pay to acquire a good or service. It could be defined as the maximum amount of money that may be contributed by an individual to equalize a utility change. The WTP function identifies that the price an individual is willing to pay for a given level of quality as given specific levels of price (P) and utility (U) (Lusk and Hudson, 2004). Contingent valuation method is a hypothetical valuation method which uses survey response to elicit consumers' willingness to pay (Maynard and Franklin, 2003)

The Logit model assumes that the random variable Zi predicts the log of the odds ratio of consumers' willingness to pay for more (LWTP). Thus,

$$
\begin{aligned}
\text { LWTP }=Z i= & \ln \left(P_{i} / 1-P_{i}\right)=\beta_{0}+\beta_{1} A+\beta_{2} E+\beta_{3} F+\beta_{4} \\
& Y+\beta_{5} D+\beta_{6} P f+\beta_{7} P S+\beta_{8} T
\end{aligned}
$$

where, LWTP $=$ Log odds ratio of the WTP, Zi $=$ the log of the odds ratio, $\mathrm{Pi} / 1-\mathrm{Pi}=$ the odds ratio, $\mathrm{A}=$ age in years of the head of the household, $E$ = education level of the head of the household, $\mathrm{F}=$ family size in numbers, $\mathrm{Y}=$ monthly income in rupees, $D=$ proximity to buying source $(\mathrm{km}), \mathrm{Pf}=$ price of fish in rupees, $\mathrm{Ps}=$ price of substitutes (meat - weighted average) in rupees, $\mathrm{T}=$ preferences (Ranks weighing from 1-5).

The probability of consumers' WTP for high value fishes is modelled as a function of various individual consumers and household level factor. The model is represented as follows

$P_{i}=e^{z i} /\left(1+e^{z i}\right)$

Where, $P_{i}=$ the probability of the ith consumers' willingness to pay more

The dependent variable is the consumer's decision on willingness to pay (WTP) for the high value fishes. It assumes 1 if the consumer is willing to pay more for high value fishes and 0 otherwise. Logit model was used to describe the consumer's decision on whether or not they agreed to pay for existing supply available or for increased supply available. The Garette Ranking Technique (Garrett, 1969) was employed to rank the problems in fish consumption as expressed by the consumers. The different problems in fish consumption as perceived by the consumers were derived based on the reconnaissance study. The order of merit given by the consumers was transmitted into scores. For converting the scores assigned by the consumers towards the particular problem, percent position was worked out using the formula- 
Percent position $=\frac{100\left(\mathrm{R}_{\mathrm{ij}}-0.05\right)}{\mathrm{Nj}}$

Where, $R_{i j}=$ Rank given for the ith problem by the jth consumer, $\mathrm{Nj}=$ Number of attributes.

\section{Results and discussion}

\section{A. Socioeconomic profile}

\section{(i) Age and educational status of head of households}

Majority of the respondents fall under age group of 36 to 60 in all the three locations. Among the total 74.6 percent of head of households belong to 36 to 60 age group, 10.6 percent of the respondents belong to the age group of more than 60 years. The young (below 35 years) were only 14.8 percent of the sample households. The educational status of head of households, region wise indicated that among the respondents 42.2 percent possessed secondary education followed by collegiate level (32.4 percent). The high school level education was possessed by 23.7 percent of the respondents. Education level was found to be generally very high as indicated by a low level of primary education (2.4 percent).

\section{(ii) Income levels of households}

Income is one of the most important determinants which positively affect fish demand. The average income level of households is shown in Table 1. The average levels of household income indicated that 39.1 percent of the

Table 1. Income levels of households (.) (Average)

\begin{tabular}{lllll}
\hline $\begin{array}{l}\text { Income (In Thousands } \\
\text { rupees) }\end{array}$ & Chennai & Mumbai & Cochin & Total \\
\hline Less than 25 & $72(40.0)$ & $61(33.9)$ & $78(43.3)$ & $211(39.0)$ \\
\hline $25-50$ & $40(22.2)$ & $58(32.2)$ & $65(36.1)$ & $163(30.9)$ \\
\hline $50-100$ & $52(28.9)$ & $43(23.9)$ & $23(12.8)$ & $118(21.8)$ \\
\hline More than 100 & $16(8.9)$ & $18(10.0)$ & $14(7.8)$ & $48(8.8)$ \\
\hline Total & $180(100.0)$ & $180(100.0)$ & $180(100.0)$ & $540(100.0)$ \\
\hline
\end{tabular}

${ }^{*}$ Figures in parenthesis indicate percentage to the total

households had an income of less than ₹ 25,000 followed by 30.9 percent with $₹ 25-50,000,21.8$ percent of the respondent households possessed an income of ₹ 50000 to 100,000 . The income level of more than a lakh was seen in 8.90 percent of the households. The average income of a Mumbai household was found to be highest ( $₹ 40859$ ) followed by Chennai ( $₹$ 39648) and Cochin (₹ 28867).
Table 2. Proximity to buying source

\begin{tabular}{lllll}
\hline Distance & Chennai & Mumbai & Cochin & Total \\
\hline Less than one km & $49(27.2)$ & $41(22.8)$ & $78(43.3)$ & $168(31.2)$ \\
\hline $1-2 \mathrm{~km}$ & $61(33.9)$ & $52(28.9)$ & $42(23.3)$ & $155(28.7)$ \\
\hline $2-3 \mathrm{~km}$ & $45(25.0)$ & $49(27.2)$ & $38(21.1)$ & $132(24.4)$ \\
\hline More than $3 \mathrm{~km}$ & $25(13.9)$ & $38(21.1)$ & $22(12.3)$ & $85(15.7)$ \\
\hline Total & $180(100.0)$ & $180(100.0)$ & $180(100.0)$ & $540(100.0)$ \\
\hline *Fiqures in parenthesis indicate percentaqe to the total
\end{tabular}

\section{(iii) Proximity to buying source}

The proximity of the buying source of fish adds to its increased demand. The proximity to buying source is well represented in Table 2 .The results indicated that 168 respondents were in close proximity to fish buying source of less than one $\mathrm{km}$. Again 155 households and 132 households were in proximity to fish buying source of between $1-2 \mathrm{~km}$ and 2-3 km respectively. It was found that 15.74 percent of the respondents had to access the fish buying source from more than $3 \mathrm{~km}$.

\section{B. Expenditure and consumption patterns \\ (i) Monthly expenditure pattern}

Analysis of the average monthly expenditure pattern on different items showed that food incurs the maximum monthly expenditure in all the three locations (Table 3). The average expenditure is calculated to be the highest in Mumbai

Table 3 Household expenditure pattern (Monthly Average) (in Rupees)

\begin{tabular}{llll}
\hline Items & Chennai & Mumbai & Cochin \\
\hline Food & 7843.20 & 8452.24 & 5563.70 \\
\hline Clothing & 2428.20 & 2973.88 & 1451.40 \\
\hline Shelter & 2644.80 & 4005.89 & 2419.00 \\
\hline Fuel/Electricity & 3662.25 & 3822.64 & 2177.10 \\
\hline Health care & 2465.25 & 2459.48 & 2177.10 \\
\hline Education & 3471.30 & 4324.18 & 2660.90 \\
\hline Social Expenses & 4631.25 & 3690.82 & 3628.50 \\
\hline Others & 1353.75 & 2420.90 & 4112.30 \\
\hline Total & 28500.00 & 32150.00 & 24190.00 \\
\hline
\end{tabular}

*Figures in parenthesis indicate percentage to the total

followed by Chennai and Cochin. The average percentage monthly expenditure for food is calculated to be the highest for Chennai (27.5 percent) followed by Mumbai (26.9 percent) and Cochin (23 percent). Clothing incurs a comparatively less monthly expenditure along the three locations, viz, 8.5 percent in Chennai, 9.2 percent in Mumbai and 6 percent in Cochin. Monthly social expenditure is calculated to be the highest in Chennai (16.5 percent) and lowest in Mumbai (11.8 percent). 
Education expenses features an average of 12.2 percent across the three locations. The average expenditure to income was found to be highest for a Cochin households (83.9 percent) followed by Mumbai (78.8 percent) and Chennai Cochin (71.8 percent).

\section{(ii) Monthly average expenditure incurred on food}

The average expenditure incurred on different food items per month along different locations is furnished in Table 4. It is seen that the average expenditure incurred is highest for cereals compared to other food items in all the three locations. The average expenditure incurred for cereals is found to be

Table 4. Household expenditure on food (Average)

\begin{tabular}{lccc}
\hline Items & Chennai & Mumbai & Cochin \\
\hline Cereals & $1843(23.5)$ & $1627(19.2)$ & $1279(23.0)$ \\
\hline Pulses & $666(8.5)$ & $862(10.2)$ & $496(8.9)$ \\
\hline Oil & $200(2.6)$ & $294(3.5)$ & $130(2.3)$ \\
\hline Fruits \& Vegetables & $955(12.2)$ & $979(11.6)$ & $460(8.3)$ \\
\hline Milk \& Dairy products & $980(12.5)$ & $1046(12.4)$ & $634(11.4)$ \\
\hline Beverages & $484(6.2)$ & $440(5.2)$ & $284(5.1)$ \\
\hline Meat \& Meat products & $1029(13.1)$ & $1362(16.1)$ & $862(15.5)$ \\
\hline Fish \& Fish products & $897(11.4)$ & $1259(14.9)$ & $924(16.6)$ \\
\hline Others & $785(10.0)$ & $580(6.9)$ & $488(8.9)$ \\
\hline Total & $7843(100.0)$ & $8452(100.0)$ & $5563(100.0)$ \\
\hline
\end{tabular}

${ }^{*}$ Figures in parenthesis indicate percentage to the total

the highest in Chennai followed by Mumbai and Cochin .The average expenditure for meat $\&$ meat products as well as fish $\&$ fish products is found to be the highest in Mumbai. The average expenditure for meat $\&$ meat products is found to be the lowest in Cochin while the same for fish \& fish products is found to be the lowest for Chennai.

\section{(iii) Average expenditure on meat and fish products}

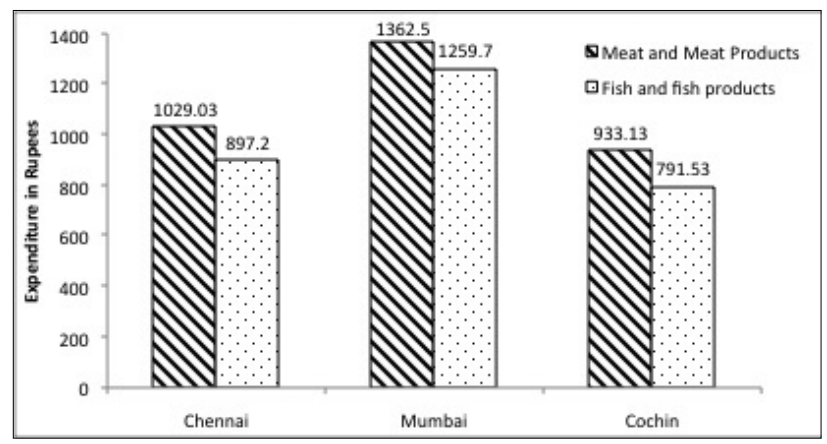

Fig. 1. Household expenditure on meat and fish products (₹.)
It can be seen that the total expenditure incurred for meat and fish products in rupees is the highest for Mumbai followed by Chennai and Cochin (Fig.1). The average percentage expenditure in Mumbai is calculated to be ₹ 51.9 for meat $\&$ meat products whereas the same for fish \& fish products is calculated to be ₹ 48.3 out of the total expenditure of ₹ 2622 for meat \& fish products. Of the total expenditure on meat \& fish products of ₹ 1926 in Chennai, 53.4 percent is on account of meat \& meat products and 46.8 percent is on account of fish \& fish products. Similarly, out of the total expenditure on meat \& fish products of ₹ 1724 in Cochin, 54.1 percent is on account of meat $\&$ meat products and 45.9 percent is on account of fish and fish products

\section{(iv) Household consumption of meat and fish products}

Meat and meat products are found to be close substitutes to fish and fish products consumption and is believed to increase with income. The monthly consumption $(\mathrm{kg})$ is found to be the highest for chicken in all the three locations (Table 5). Among Monthly chicken consumption is found to be the highest in Mumbai followed by Chennai and Cochin. It can be seen that

Table 5. Average monthly household consumption of meat and fish products $(\mathrm{kg})$

\begin{tabular}{lllll}
\hline Item & Chennai & Mumbai & Cochin & Average \\
\hline Chicken & 3.06 & 3.91 & 2.62 & 3.20 \\
\hline Mutton & 1.25 & 1.68 & 0.91 & 1.28 \\
\hline Beef & 1.30 & 1.38 & 1.38 & 1.35 \\
\hline Pork & 0.00 & 0.24 & 0.50 & 0.25 \\
\hline Other meat products & 0.75 & 0.21 & 0.36 & 0.44 \\
\hline Fish -Low value fishes & 7.02 & 5.76 & 6.70 & 6.49 \\
\hline Fishes High value fishes & 2.45 & 3.67 & 2.42 & 2.85 \\
\hline
\end{tabular}

the low value fishes are consumed more than the high value fishes in all of the three locations. Low value fishes are highly consumed in Chennai whereas high value fishes are highly consumed in Mumbai. The lowest consumption of low value fishes is found to be in Mumbai whereas the same for high value fishes is found in Cochin when compared among the three locations.

\section{(v) Fish consumption pattern}

The average fish consumption of low value fishes is found to be the highest in Chennai followed by Cochin and Mumbai whereas the average fish consumption of high value fishes is found to be the highest in Mumbai followed by Chennai and Cochin. Chennai reported the highest average monthly consumption of fish followed by Mumbai and Cochin. 


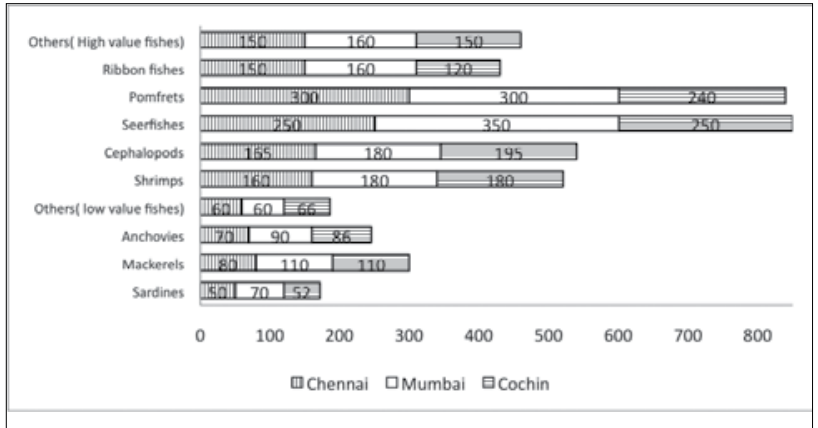

Fig. 2. Average prices paid for fishes in selected locations (₹.) (Prices were taken for uniform size range and counts)

Sardine was mostly consumed in Chennai and Cochin whereas mackerel was the favoured one in Mumbai. Among high value fishes, shrimp was consumed most in Mumbai and Chennai whereas pearl spot among others was favoured in Cochin household. It was interesting to note that seer fish, cephalopods, pomfrets and ribbon fishes were found to be consumed in all the three locations

Table 6. Fish consumption (Quantity in $\mathrm{kg}$ )

\begin{tabular}{lllll}
\hline Category & Chennai & Mumbai & Cochin & Average \\
\hline Sardines & 2.61 & 1.19 & 2.87 & 2.22 \\
\hline Mackerels & 1.30 & 2.63 & 1.29 & 1.74 \\
\hline Anchovies & 1.29 & 0.59 & 1.20 & 1.03 \\
\hline Others (low value fishes) & 1.82 & 1.35 & 1.34 & 1.50 \\
\hline Total- Low value fish & 7.02 & 5.76 & 6.70 & 6.49 \\
\hline Shrimps & 1.02 & 1.25 & 0.22 & 0.83 \\
\hline Cephalopods & 0.2 & 0.44 & 0.41 & 0.35 \\
\hline Seer fishes & 0.54 & 0.40 & 0.43 & 0.46 \\
\hline Pomfrets & 0.25 & 0.62 & 0.23 & 0.37 \\
\hline Ribbon fishes & 0.10 & 0.58 & 0.32 & 0.33 \\
\hline Others (High value fishes) & 0.34 & 0.38 & 0.81 & 0.51 \\
\hline Total- High value fish & 2.45 & 3.67 & 2.42 & 2.85 \\
\hline Average & 9.47 & 9.43 & 9.12 & 9.34
\end{tabular}

${ }^{*}$ High value fishes were denoted as fishes which realize a retail price of more than Rs $150 / \mathrm{kg}$

The average price of fishes across Chennai, Mumbai and Cochin is indicated in fig. 2. The average price of high value fishes was kept at ₹ 150 for all the three locations. Average price of low value fishes is found to be ₹ 60 for Chennai and Mumbai whereas the same is calculated to be $₹ 66$ for Cochin. The highest average price of $₹ 350$ was realised for seer fishes in Mumbai while the lowest average price of ₹ 52 was for sardines in Cochin. The results indicated that price differentials amongst the different consumption locations weren't high.
Table 7. Problems in domestic consumption - Garrete ranking

\begin{tabular}{llcccccc}
\hline $\begin{array}{l}\text { Sl. } \\
\text { No: }\end{array}$ & Reasons & \multicolumn{2}{c}{ Chennai } & \multicolumn{2}{c}{ Mumbai } & \multicolumn{2}{c}{ Cochin } \\
\hline & & Score & Rank & Score & Rank & Score & Rank \\
\hline 1. & $\begin{array}{l}\text { Non availability of } \\
\text { preferable fishes }\end{array}$ & 52.2 & V & 52.2 & V & 28.4 & VI \\
\hline 2. & Lack of fresh fish & 56.9 & I & 55.9 & II & 52.2 & V \\
\hline 3. & $\begin{array}{l}\text { Wide fluctuations } \\
\text { in price }\end{array}$ & 28.4 & VI & 53.5 & IV & 55.9 & II \\
\hline 4. & High price & 54.4 & III & 54.4 & III & 56.9 & I \\
\hline 5. & $\begin{array}{l}\text { Nearness to the } \\
\text { source of purchase }\end{array}$ & 53.5 & IV & 56.9 & I & 54.4 & III \\
\hline 6. & $\begin{array}{l}\text { Restricted to } \\
\text { religious reasons / } \\
\text { social functions }\end{array}$ & 55.9 & II & 28.4 & II & 53.5 & IV \\
\hline & & & & & & \\
\hline
\end{tabular}

\section{Constraint analysis on fish consumption}

The main constraint observed in Chennai was lack of fresh fish, followed by consumption restricted due to religious reasons/ social functions, high price, nearness to the source of purchase, non-availability of preferable fishes, and wide fluctuations in price (Table 7). High price was the main constraint observed in Cochin preceded by wide fluctuations in price, nearness to the source of purchase, consumption restricted to social functions, lack of fresh fish and non-availability of preferable fishes. Nearness to the source of purchase is found to be the main problem followed by lack of fresh fish, high price, wide fluctuations in price and non-availability of preferable fishes in Mumbai.

\section{Status on the awareness about high value fishes consumption}

Table 8. Awareness on high value fish consumption (Percentage of respondents)

\begin{tabular}{|c|c|c|c|c|}
\hline $\begin{array}{l}\text { Sl. } \\
\text { No: }\end{array}$ & Parameter & Chennai & Mumbai & Cochin \\
\hline 1. & $\begin{array}{l}\text { Awareness on the low export } \\
\text { prices of high value fishes }\end{array}$ & 12.6 & 14.3 & 18.3 \\
\hline \multirow[t]{6}{*}{2.} & Preference to eat if available & & & \\
\hline & Never & 13.4 & 14.3 & 18.4 \\
\hline & Very Rarely & 22.2 & 20.4 & 21.5 \\
\hline & Rarely & 25.5 & 26.2 & 32.3 \\
\hline & Frequently & 26.4 & 26.8 & 17.3 \\
\hline & Very frequently & 12.5 & 12.3 & 10.6 \\
\hline \multirow[t]{6}{*}{3.} & Do you get high value fishes & & & \\
\hline & Never & 13.3 & 13.1 & 12.5 \\
\hline & Very Rarely & 29.4 & 20.2 & 28.3 \\
\hline & Rarely & 28.4 & 35.8 & 31.4 \\
\hline & Frequently & 18.5 & 18.5 & 16.5 \\
\hline & Very frequently & 10.5 & 12.4 & 11.4 \\
\hline 4. & $\begin{array}{l}\text { Are you ready to pay more price if } \\
\text { available - Yes }\end{array}$ & 48.2 & 63.4 & 38.4 \\
\hline
\end{tabular}


A sizeable portion of the respondents from metros opined (Table 8) that they rarely get high value fishes. A sizeable portion of the respondents in the three locations preferred to eat fish if available frequently i.e. in the order of 26.8 percent in Mumbai, 26.4 percent in Chennai and 17.3 percent in Cochin.

\section{E. Willingness to pay-functions}

The WTP for high value fishes was estimated separately for the three consumption locations and the functional form of the WTP is given below

$$
\begin{aligned}
\text { LWTP =Zi }= & \ln (\mathrm{Pi} / 1-\mathrm{Pi})=\beta 0+\beta_{1} A+\beta_{2} E+\beta_{3} F+\beta_{4} Y \\
& +\beta_{5} D+\beta_{6} \mathrm{Pf}+\beta_{7} \mathrm{PS}+\beta_{8} \mathrm{~T}
\end{aligned}
$$

\section{(a) Chennai}

$$
\begin{aligned}
& Z i=0.382+0.182 A+0.168 E-0.139^{* *} F+0.062^{* *} Y- \\
& \begin{array}{lllll}
(1.424) & (1.124) & (1.112) & (-1.089) & (0.414)
\end{array} \\
& \begin{array}{l}
0.014 \mathrm{D} \\
(-1.124) \\
(-1.118)
\end{array} \underset{0.181^{* *}}{\mathrm{Pf}}+\underset{(1.131)}{0.18 \mathrm{Ps}}+\underset{(0.612)}{0.0048 \mathrm{~T}}
\end{aligned}
$$

$\mathrm{R}^{2}=0.783$

** one percent level of significance * five percent level of significance; values in parenthesis indicates estimated ' $\mathrm{t}$ ' ratios

The results indicated that the WTP for fish had positive association with income, price of fish, price of substitutes and taste and preferences. The WTP was adversely affected by family size and proximity to the buying source. It was found that for every increase in the price of fish leads to an added demand in the WTP for high value fishes.

(b) Mumbai

$$
\begin{aligned}
& \text { LWTP }=Z i=\begin{array}{rrrrr}
0.421+ & 0.106 & A+0.129 E & -0.169^{\star *} & F \\
& (1.692) & (1.104) & (1.124) & (1.491)
\end{array} \\
& +0.0131^{* *} \gamma-0.361 \mathrm{D}+0.262^{* *} \mathrm{Pf}+0.219 \\
& \begin{array}{llll}
(0.918) & (-1.179) \quad(-1.098) \quad(1.342)
\end{array} \\
& P_{s}+0.0189 \mathrm{~T} \\
& \text { (0.512) } \\
& \mathrm{R}^{2}=0.691
\end{aligned}
$$

** one percent level of significance * five percent level of significance; values in parenthesis indicate estimated ' $t$ ' ratios
The results indicated that the WTP for fish had positive association with income, price of substitutes and taste and preferences. The WTP was adversely affected by family size, proximity to the buying source. It was found that for every ten percent increase in the family size decreases the WTP decreases by 1.7 percent from the mean level ceteris paribus. Against the classical demand theory of decreasing demand with increased prices it was found that the consumer's WTP for high value fishes was more with increasing price of fish thus indicating a high consumer surplus. It was also found that for every 10 percent increase in the price of fish leads to an added demand in the WTP for high value fishes by 2.6 percent from the mean level ceteris paribus.

(c) Cochin

$$
\begin{aligned}
& \text { LWTP }=\mathrm{Zi}=0.410+0.261 \quad \mathrm{~A}+0.142 \mathrm{E}-0.183^{\star \star} \mathrm{F}+ \\
& \begin{array}{llll}
(1.424) \quad(1.124) \quad(1.112) \quad(-1.089) & 0
\end{array} \\
& 0.081^{* *} Y-0.119 D-0.172^{* *} P_{f}+0.242 P_{s}+ \\
& \text { (0.414) (-1.124) (-1.118) (1.131) } \\
& 0.0162 \mathrm{~T} \\
& (0.612)
\end{aligned}
$$

** one percent level of significance * five percent level of significance; values in parenthesis indicates estimated ' $\mathrm{t}$ ' ratios

The results indicated that the WTP for fish had positive association with income, price of substitutes and taste and preferences. The WTP was adversely affected by family size, proximity to the buying source and price of fish. It was found that for every ten percent increase in the family size, the WTP decreases by 1.8 percent from the mean level ceteris paribus. It was found that for every 10 percent increase in the price of fish leads to reduced WTP for high value fishes by 1.7 percent from the mean level ceteris paribus. However, increase in price of substitutes by 10 percent would lead to increased WTP for fish by 2.4 percent from the mean level ceteris paribus.

(d) All locations

$$
\begin{aligned}
& \text { LWTP }=\mathrm{Zi}=0.432+0.142 \mathrm{~A}+0.109 \mathrm{E}-0.105^{* *} \mathrm{~F}+ \\
& \begin{array}{llll}
(1.612) & (1.189) \quad(1.112) \quad(-1.713)
\end{array} \\
& 0.021^{\text {* }} \text { - }-0.0138 \mathrm{D}+0.089^{\text {** }} \mathrm{Pf}+0.218+\text { Ps }+ \\
& \text { (0.398) (-1.089) (1.101)(1.411) } 0.0146 \mathrm{~T}(0.592)
\end{aligned}
$$

$\mathrm{R}^{2}=0.812$ 
** one percent level of significance * five percent level of significance; values in parenthesis indicates estimated ' $\mathrm{t}$ ' ratios

The results indicated that the WTP for fish had positive association with age, education, income, price of substitutes and taste and preferences. The WTP was adversely affected proximity to the buying source. Against the classical demand theory of decreasing demand with increased prices it was found that the consumer's WTP for high value fishes increased with increasing fish prices indicating a high consumer surplus. It was found that for every ten percent increase in the price of fish the WTP increases by 0.8 percent from the mean level ceteris paribus. The WTP function analysis indicates that contrary to the classic demand theory the demand for fish exists even though with increasing prices as indicated for Mumbai and pooled consumers. The WTP function also ascertains the growing demand for fish consumption even with high prices.

The fish food consumption pattern indicated that there exists considerable demand for fish and fish products in the different parts of the country. The study indicated that the average monthly household fish demand was found to be $9.34 \mathrm{~kg}$ distributed across low value $(6.49 \mathrm{~kg})$ and high value fishes $(2.85 \mathrm{~kg})$.The average amount spent for fish and fish products was found to be ₹ 982.81. The Garrett ranking analysis indicated that the non-availability of preferable fishes, lack of fresh fish, wide fluctuations in price, high price, nearness to the source of purchase and consumption restricted to social functions were the major constraints in fish consumption.

It is important to note that only 15 percent of the consumers were aware about the export prices of high value fishes. It was found that 35.3 percent of the consumers were willing to frequently eat high value fishes if available and 70.8 percent felt the unavailability of high value fishes for consumption. Around 50 percent of the consumers opined that they were willing to pay for fish if available. The WTP function indicated that there exists a demand for high value fish consumption even with higher prices. The non-availability of fish in the domestic fish market will lead to a situation wherein the domestic consumers are devoid of fish in the market at affordable prices. Thus it is important to ensure that the availability and affordability of high value fishes whose consumption could be augmented by creating awareness campaigns in the country. In addition, governmental regulations are required for enabling a sizeable quantum to be marketed locally.

\section{Acknowledgements}

The author thanks Director, Central Marine Fisheries Research Institute, Cochin for fund and facilities provided.

\section{References}

Delgado Christopher L., Nicholas Wada, Mark W. Rosegrant, Siet Meijer and Mahfuzuddin Ahmed. 2003. Outlook to Fish for 2020: Supply and Demand in Changing Global Markets, International Food Policy Research Institute, Washington D.C., USA and World Fish Centre, Penang, Malaysia, October, 2003.

FA0. 2005. National Aquaculture Sector Overview. India. National Aquaculture Sector Overview Fact Sheets Text nu Gias, U.A. In: FAO Fisheries and Aquaculture Department (online) Rome updated 1 January 2005

Garrett, H. E. and R. S.Woodworth.1969. Statistics in Psychology and Education, Vakils, Feffer and Simons Pvt. Ltd., Bombay. 329 pp.

Krishnan, M and S. Pratap. Birthal. 2002. WTO and seafood exports: performance, policy and potential, Ind. J. of Agri. Mktg., Annl. Conf. vol., p.103-112

Krishnan, M.1997. A Corporate Strategy for "Fish for All" In India. In Pillai, N.G.K and Pradeep.K.Katiha, Evolution of Fisheries' an Aquaculture in India ,p. 240 Central Marine Fisheries Research Institute Kochi India- 18 ISBN:81-901219-4.4

Lusk, L. and D. Hudson. 2004. Willingness-to-pay estimates and their relevance to agribusiness decision making, Review. Agri. Econ., 26: 152-169

Maynard, L and S. Franklin. 2003. Functional foods as a value-added strategy: the commercial potential of "cancer-fighting" dairy products. Review. Agri. Econ., 25: 316-331.

Sandu Joseph and Shyam. S. Salim. 2012. Indian Seafood Trade: Implications, issues and policy imperatives. Seafood Exp. J., 42 (11): 36-42.

Sathiadas, R. 1998. Price spread of marine fish and need for cooperative fish marketing. Ind. Cooperative Rev., 36 (2):166-170.

Shyam S. Salim and R. Geetha. 2011. Stakeholders perception of Indo-ASEAN Free Trade Agreement on Indian Fish. Sector. J. Ind. Fish. Assoc., (38):1-9.

Shyam S. Salim, 2012. Consumer's Willingness to pay more for shrimps in Suburban Mumbai, Agri. Econ. Res. Rev., 25 (2), July-December 2012, pp 347-350

Shyam S. Salim, R. Sathiadhas, T. V. Sathianandan, R. Geetha, N. Aswathy, V. P. Vipinkumar, 2010. Marine fisheries resources: exploitation, management and regulations in India Seafood Exp. J., 40 (2): 25-34.

Sutanuka, Ghosal, 2011. Domestic fish prices jump on soaring demand in tier-II and tier-III cities. The Economic Times, August 1 pp. A3-A4 